\title{
Synthesis of nanocrystalline titanium dioxide for photodegradation treatment of remazol brown dye
}

\author{
K. Santhi $\cdot$ P. Manikandan $\cdot$ C. Rani $\cdot$ \\ S. Karuppuchamy
}

Received: 26 March 2014 / Accepted: 5 June 2014/Published online: 27 June 2014

(C) The Author(s) 2014. This article is published with open access at Springerlink.com

\begin{abstract}
A nanocrystalline $\mathrm{TiO}_{2}$ was successfully synthesized using simple aqueous peroxo route and subsequently the surface characterization of $\mathrm{TiO}_{2}$ was carried out using X-ray diffraction and Scanning electron microscopy. The synthesized nanocrystalline $\mathrm{TiO}_{2}$ successfully decomposed the aqueous remazol brown dye solution under UV light irradiation with and without ozone. The effects of $\mathrm{pH}, \mathrm{TiO}_{2}$ dose and irradiation time for decomposition of dye solution were also evaluated. The maximum dye decomposition efficiency of $96.6 \%$ was achieved with the minimal time of $45 \mathrm{~min}$ by $\mathrm{UV} / \mathrm{TiO}_{2} / \mathrm{O}_{3}$ treatment. The present study clearly indicates that the peroxo route $\mathrm{TiO}_{2}$ nanoparticle is a promising material for industrial waste water treatment.
\end{abstract}

Keywords Nanocrystalline - Titanium dioxide .

Photocatalysis - Remazol brown dye

\section{Introduction}

Wastewater pollution is one of the major problems in the textile industry and other industries such as thermal power

K. Santhi · C. Rani

Department of Chemistry, Alagappa Government Arts College,

Karaikudi, Tamilnadu 630 004, India

P. Manikandan

Department of Chemistry, Kongu Engineering College,

Perundurai, Tamilnadu 638 052, India

S. Karuppuchamy $(\bowtie)$

Department of Energy Science, Alagappa University, Karaikudi,

Tamilnadu 630 004, India

e-mail: skchamy@gmail.com;

skchamy@alagappauniversity.ac.in plants, leather, plastics, cosmetics, steel, engineering, pulp and paper, sugar, fertilizer and food industries. A lot of research work is going on to mitigate/solve the water pollution problem. Various methods have been developed for waste water treatment such as physical treatment [sedimentation (Fiola and Luce 1998), equalization, segregation and filtration], physico-chemical treatment [Chemical coagulation/flocculation (Schulze-Rettmer 1998), ion exchange, adsorption (Papic et al. 2000), chemical oxidation using ozone, chemical oxidation using hydrogen peroxide], biological treatment [aerobic treatment, anaerobic treatment]. All these techniques are useful; however, they are producing some secondary waste products which required further treatment (Zhou and Smith 2002; Baban et al. 2003). Alternatively, the photocatalytic oxidation process to oxidize the organic pollutants in wastewater with free radicals has been attracting a tremendous interest among the researchers. Photocatalytic oxidation process with metal oxides is one of the promising techniques to break down the organic pollutants. Among the metal oxides, $\mathrm{TiO}_{2}$ is one of the most attractive and capable candidates for degradation of waste water from many industries (Kawahara et al. 2007; Kawahara et al. 2007; Matsui et al. 2007; Matsui et al. 2007, 2009; Karuppuchamy and Ito 2008; Neppolian et al. 2002; Sökmen and Özkan 2002; Muruganandham and Swaminathan 2004). Nanostructured $\mathrm{TiO}_{2}$-based photocatalytic process attracts due to its several advantages such as a high refraction index, biocompatibility, corrosion resistance, low cost, availability, and non-toxic. A number of methods were proposed to prepare nanostructure $\mathrm{TiO}_{2}$ including microwave irradiation, chemical vapor deposition, spray pyrolysis, electrochemical deposition and sol-gel method. For the industrial applications, $\mathrm{TiO}_{2}$ nanoparticles could be synthesized from a solution of either titanium salts or 
titanium alkoxides. $\mathrm{TiOSO}_{4}$ is particularly appealing as a raw material of $\mathrm{TiO}_{2}$ owing to its low cost. A major portion of commercial $\mathrm{TiO}_{2}$ particles is currently produced by neutralization of $\mathrm{TiOSO}_{4}$ aqueous solutions followed by the annealing of the precipitates. Amorphous titanium hydrous oxide with micrometer-sized particles has also been produced using $\mathrm{TiOSO}_{4}$ and urea. However, the particles synthesized in the above conventional ways are not suitable for many applications because of the very low surface area. The objective of this piece of work is to develop the novel synthetic route to fabricate nanostructured $\mathrm{TiO}_{2}$ (Tang and Chen 2004; Meric et al. 2004; Akyol et al. 2004; Chin 2005; Muruganandham et al. 2006; Kansal et al. 2007). The present paper is dedicated to report the synthesis, structural characterization and photocatalytic investigations of the nanostructured $\mathrm{TiO}_{2}$.

\section{Materials and methods}

Preparation and characterization of $\mathrm{TiO}_{2}$ nanoparticles

Chemicals were purchased from commercial sources. They were used without further purification. Doubly distilled water and ion exchanged water were used in all the experiments. $\mathrm{TiO}_{2}$ nanoparticles were prepared from aqueous peroxo-titanium solution that has been described elsewhere (Kauppuchamy and Jeong 2006). In brief, Titanium oxy sulphate $\left(\mathrm{TiOSO}_{4} \cdot 5 \mathrm{H}_{2} \mathrm{O}\right)$ was dissolved in water at room temperature and then $\mathrm{H}_{2} \mathrm{O}_{2}$ was added into this solution at various concentrations. A yellow colored solution was immediately obtained, which confirms the formation of peroxo complex of Titanium solution. This yellow colored peroxo-titanium solution produces a water insoluble yellow gel, titanium oxy-hydroxide after keeping at room temperature for few hours. Then, the yellow gel was separated by centrifugation and dried overnight in the oven. Finally, the dried yellow powder was calcined in air at different temperatures. The calcined powder was analyzed by an X-ray diffractometer (RIGAKU RAD-2R) with $\mathrm{CuK} \alpha$ radiation. The particle shape and morphology was observed using field emission-SEM (FE-SEM HITTACHI S-4300Se/N).

\section{Photocatalytic measurements}

Remazol brown is a Double Azo Vinyl sulphone dye. It can also be called as Reactive Brown 18. Remazol brown dye is a reactive dye that was used without further purification. But the structure and molecular weight of the dye was not yet declared. It is a brown powder, soluble in water, extremely soluble in ethanol. Dye solution was prepared by dissolving requisite quantity of dye in double distilled water with a concentration of $1,000 \mathrm{ppm}$. The $\mathrm{pH}$ is an essential factor to be predictable in each and every phase of wastewater treatment. The $\mathrm{pH}$ of the dye solution was adjusted with $1 \mathrm{M} \mathrm{HCl}$ or $1 \mathrm{M} \mathrm{NaOH}$. A UV-VIS Spectrophotometer (ELICO-BL198 double-beam biospectrophotometer) was used to determine the decolourization rate. Oxidation experiments were carried out in the 100-150 ml-capacity photo-reactor as shown in Fig. 1 (UV Photo Reactor System HEBER model: HPSLIV16254), which was operated in batch mode. The reactor was provided with a water jacket, made of quartz, and equipped with a medium pressure mercury vapor lamp emitting in the $254 \mathrm{~nm}$ range (power of $16 \mathrm{~W}$ UV lamp-Philips). Constant stirring of the solution was ensured using magnetic stirrers. The dye solution and catalyst placed in the photo-reactor were stirred thoroughly. After the photocatalytic treatment, samples were centrifuged and analyzed for the concentration of remazol brown dye solution using computer software attached to UV-Vis Spectrophotometer (Khataee et al. 2009; Alaton et al. 2008; Khataee et al. 2009; Hussein and Abass 2010; Lomora and Draghici 2011; Ehrampoush et al. 2011). Decolourization of dye solution was tested at different time intervals $(15 \mathrm{~min})$ by UV-vis spectrophotometer and the decomposition efficiency was recorded. The following equation was used to calculate the decomposition efficiency of the dye solution.

$\eta \%=\left(\mathrm{abs}_{0}-\mathrm{abs}_{t}\right) \times 100 / \mathrm{abs}_{0}$

where, $\mathrm{abs}_{0}$ and $\mathrm{abs}_{t}$ are the absorbance of the dye in solution at the beginning of the experiment and at the time $t$, respectively.

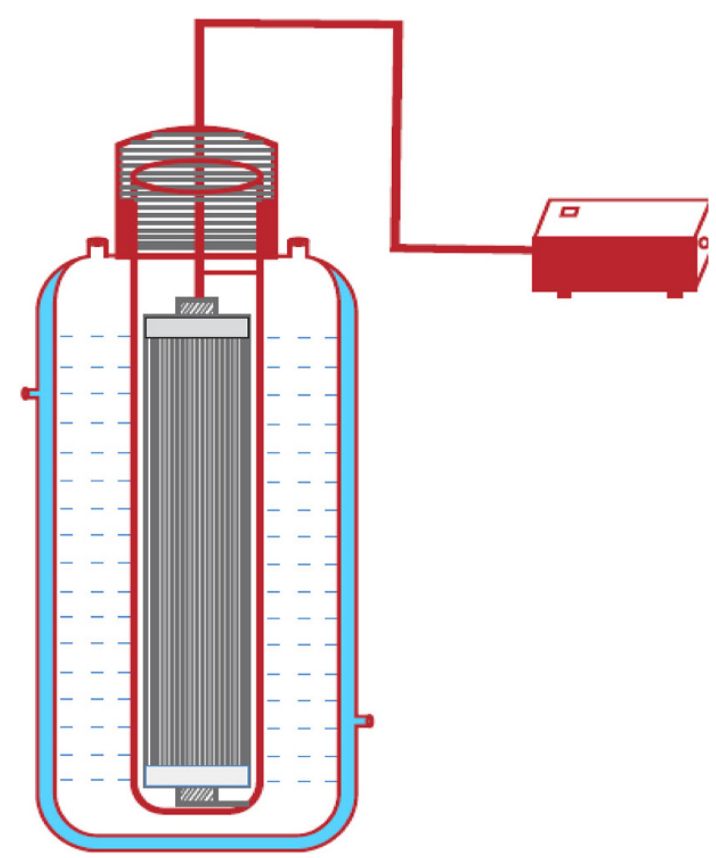

Fig. 1 Immersion-type photo-reactor 


\section{Results and discussion}

Characterization of the prepared materials

The X-ray diffraction pattern (XRD) of the as-prepared $\mathrm{TiO}_{2}$ and heat-treated powders is shown in Fig. 2. The Tioxy-hydroxide obtained from simple aqueous peroxo route was further heated at various temperatures to obtain crystalline materials. Pattern (a) (b) and (c) in Fig. 2 shows the characteristic peaks of the as-prepared and heated $\mathrm{TiO}_{2}$ powders. The as-prepared powder was amorphous, while the powder calcined at 300 and $450{ }^{\circ} \mathrm{C}$ was crystalline. The broader peaks in XRD pattern (b) suggest the possibility of low degree of crystallinity. In pattern (c), the more sharpness of the peak was obtained which indicates the increase of particle size due to the effect of calcinations. Further, to investigate the effect of calcination temperature on the crystallite growth, the crystallite size was calculated using the Scherrer's equation. Indeed, it has been found that there was an increase in crystallite size with increase of calcination temperature. A crystallite size of 27 and $39 \mathrm{~nm}$ were determined from the FWHM of the (101) peak of the anatase for the heat-treated samples at 300 and $450{ }^{\circ} \mathrm{C}$, respectively. Figure 3 presents the typical scanning electron microscope images of the as-prepared titanium dioxide powder (a) and calcined $\mathrm{TiO}_{2}$ powders (b) and (c). It reveals the morphological homogeneity with the grain size falling mostly in submicron range. Careful observation of SEM pictures clearly evinces that each grain is made up with an aggregation of (nanometer size) very small crystallites. There is a considerable difference seen between the SEM images (Fig. 3a-c). The as-prepared powder consists of non-porous aggregates which are made up of tiny crystallites. However, when the powder was calcined at 300 and $450{ }^{\circ} \mathrm{C}$, the crystallite size and the porosity were also increased. The increase of crystallite size may be due to the effect of heat treatment. The estimated crystallite size of the calcined samples also supports the crystallite growth of the samples by thermal annealing. To investigate the composition of the prepared $\mathrm{TiO}_{2}$ powder, EDX analysis was also carried out for the powder samples heated at $450{ }^{\circ} \mathrm{C}$. The EDX analysis shows that all the samples contain only titanium and oxygen elements and there was no impurity in the samples.

Photocatalytic measurements

\section{Effect of $p H$}

The photocatalytic ability of the synthesized $\mathrm{TiO}_{2}$ was examined. The $\mathrm{pH}$ is one of the most important operating factors in photocatalytic aquatic system that affects the charge of the catalyst particles and also the locations of conductance and valence bands of the catalyst. Due to the nature of $\mathrm{TiO}_{2}$ catalyst used, several variations in the functioning of $\mathrm{pH}$ are known to disturb the isoelectric point or the external charge of the photocatalysts (Saggioro et al. 2011; Joshi and Shrivastava 2011; Giwa et al. 2012; Shah et al. 2013; Ananthashankar and Ghaly 2013; Ankita et al. 2013; Yi et al. 2013; Albu 2007; Ananthashankar and Ghaly 2013). The comparative experiments were performed at three different $\mathrm{pH}$ values such as 3, 7 and 11 to decompose remazol brown dye wastewater. The samples were taken from the reactor at predetermined time intervals (15 min) and subsequently analyzed their color. The obtained results related to color are demonstrated in Fig. 4. The $\mathrm{pH}$ of the dye very much influences the decomposition reaction and the highest decomposition efficiency of dye was achieved at $\mathrm{pH} 3$. Besides, lower decomposition efficiency of dye was observed at pH 7 and 11 (Fig. 4). The decolorization reaction rate of dye was slightly faster for first $15 \mathrm{~min}$ invariably at all $\mathrm{pH}$. This may be an indicator for a predominant direct oxidation pathway over radical reactions. The dye decomposition mechanism with nanocrystalline $\mathrm{TiO}_{2}$ may be considered in three different phases with different rates, such as swift discolorization in
Fig. 2 X-ray diffractograms of $\mathrm{TiO}_{2}$ powder $a$ as-deposited and heated at $b 300$ and $c 450{ }^{\circ} \mathrm{C}$ for $1 \mathrm{~h}$ in air

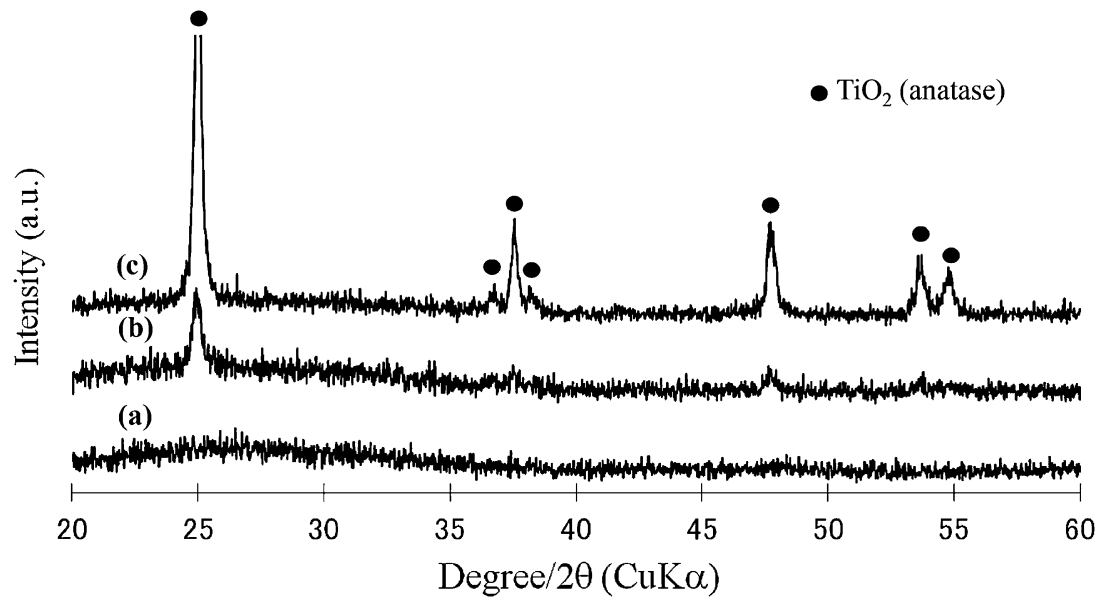

Degree $/ 2 \theta(\mathrm{CuK} \alpha)$ 

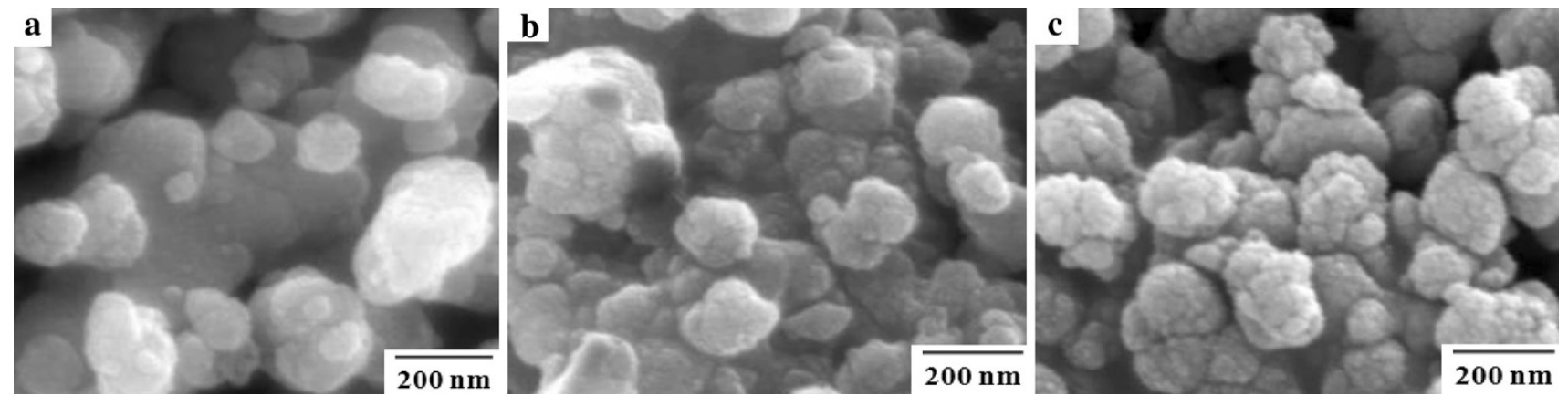

Fig. $3 \mathrm{SEM}$ photograph of the $\mathrm{TiO}_{2}$ powder a as-deposited and annealed at b $300 \mathbf{c} 450{ }^{\circ} \mathrm{C}$ for $1 \mathrm{~h}$ in air

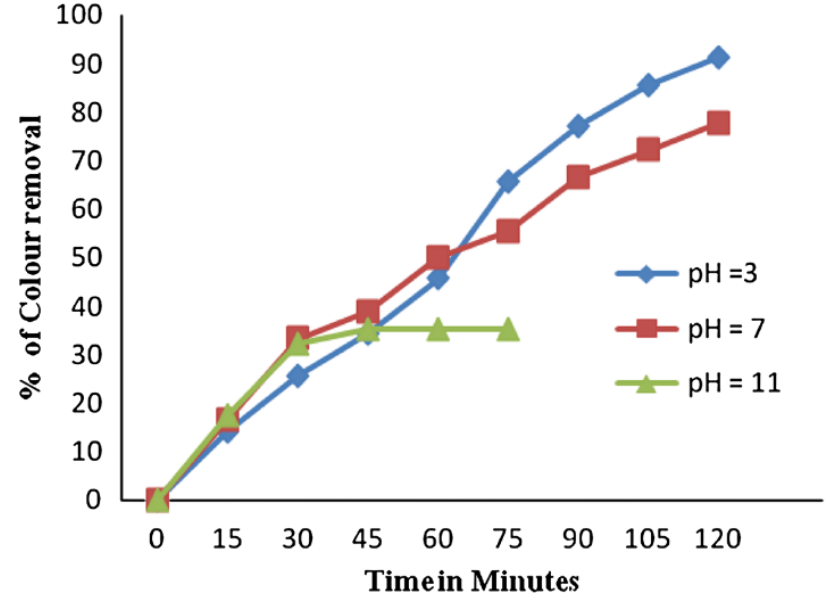

Fig. 4 Photocatalytic decolourization of remazol brown dye in the presence of $\mathrm{UV}$ and $\mathrm{TiO}_{2}$ with different $\mathrm{pH}$ at different time intervals of irradiation (Rotation speed $=1,000 \mathrm{rpm}$, initial concentration of the dye $=1,000 \mathrm{ppm}$ )

the first phase, then slower discolorization in the second phase, and no significant dye decomposition in the third phase. The surface of $\mathrm{TiO}_{2}$ has a positive charge in acidic media, so there is an electrostatic absorption between positive charge surfaces of $\mathrm{TiO}_{2}$ and the dye.

\section{Effect of $\mathrm{TiO}_{2}$ loading}

The required concentration of $\mathrm{TiO}_{2}$ for the decolourization of a 1,000 ppm remazol brown dye solution was scrutinized with the slurry method by varying the quantities of $\mathrm{TiO}_{2}(0.3,0.4$ and $0.5 \mathrm{~g})$ and the $\mathrm{pH}$ was maintained at 3 throughout out the experiment. It should be indicated that the decomposition efficiency of dye solution is high at $\mathrm{pH}$ 3 . The higher dye decomposition efficiency was reported with increasing $\mathrm{TiO}_{2}$ dose, due to the presence of highest active site for the attack of heavier molecule by the formation of active hydroxyl radicals (Figs. 5, 6). It is interesting to note that the dye was almost completely absorbed when the concentration of $\mathrm{TiO}_{2}$ was increased to $0.5 \mathrm{~g}$. This observation clearly demonstrates that an increase in the amount of catalyst to the consistent level with the optimized level of light absorption increases the amount of decolourization (Š́ma and Hasal 2013; Marathe and Shrivastava 2013). Thus, any further increase of the amount of the catalyst does not have any effect on the photodegradation efficiency.

\section{Comparative study}

The effect of semiconductor catalyst on the photocatalytic decomposition efficiency of remazol brown dye was studied in the presence and absence of ozone. The initial concentration of the dye was fixed as $1,000 \mathrm{ppm}$ and the complete treatment process was carried out at $\mathrm{pH} 3$. Figures 5 and 6 show the effect of $\mathrm{UV} / \mathrm{TiO}_{2}$ in the presence and absence of ozone. At all doses, ozonation reaction was carried out for a period of $120 \mathrm{~min}$ and the samples were taken from the reactor at predetermined time intervals (15 min) and analyzed for their decomposition efficiency. It is evident from the Fig. 7 that a combined treatment enhances the dye decomposition efficiency due to the synergetic effect of formation of hydroxyl radical and hence the mineralization is also enhanced in the treatment process. The preferential attack of ozone molecule on the unsaturated bond of dye chromophores may also be one of the influential factors for the decomposition of dye molecules.

\section{Conclusions}

Nanocrystalline $\mathrm{TiO}_{2}$ was successfully synthesized using simple aqueous peroxo route. The newly synthesized nanocrystalline $\mathrm{TiO}_{2}$ successfully decomposed the aqueous remazol brown dye solution under UV light irradiation. The maximum dye decomposition efficiency of $96.6 \%$ was achieved with the minimal time of $45 \mathrm{~min}$ by UV/ $\mathrm{TiO}_{2} / \mathrm{O}_{3}$ treatment and to achieve the same decomposition efficiency by $\mathrm{UV} / \mathrm{TiO}_{2}$ required more time. Thus, it can be concluded that the ozonation of dyeing system employed in 


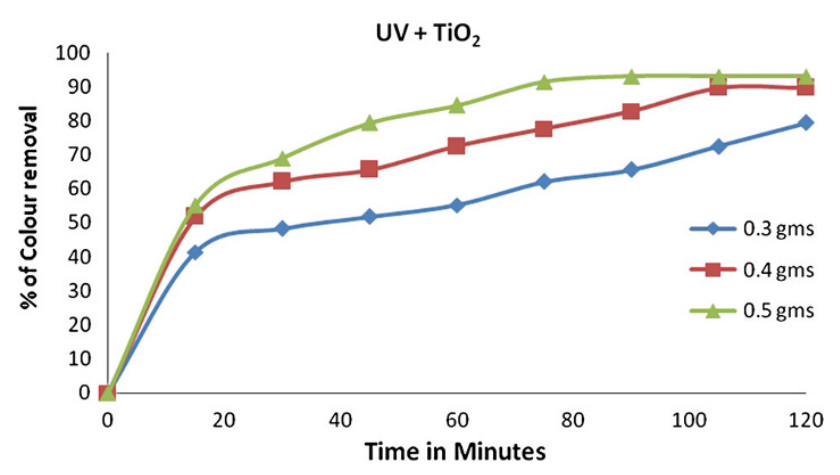

Fig. 5 Photocatalytic decolourization of remazol brown dye with different $\mathrm{TiO}_{2}$ loadings in the presence of UV at different time intervals of irradiation (Rotation speed $=1,000 \mathrm{rpm}$, initial concentration of the dye $=1,000 \mathrm{ppm}$ )

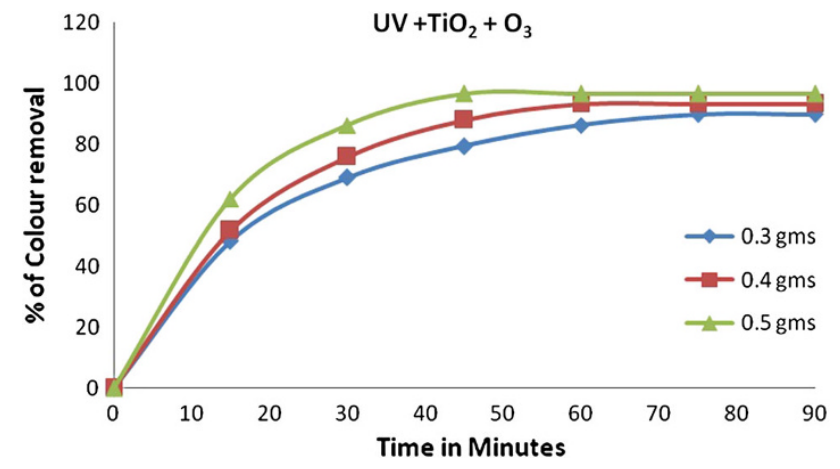

Fig. 6 Photocatalytic decolourization of remazol brown dye with different $\mathrm{TiO}_{2}$ loadings in the presence of UV and Ozone at different time intervals of irradiation (Rotation speed $=1,000 \mathrm{rpm}$, initial concentration of the dye $=1,000 \mathrm{ppm}$ )

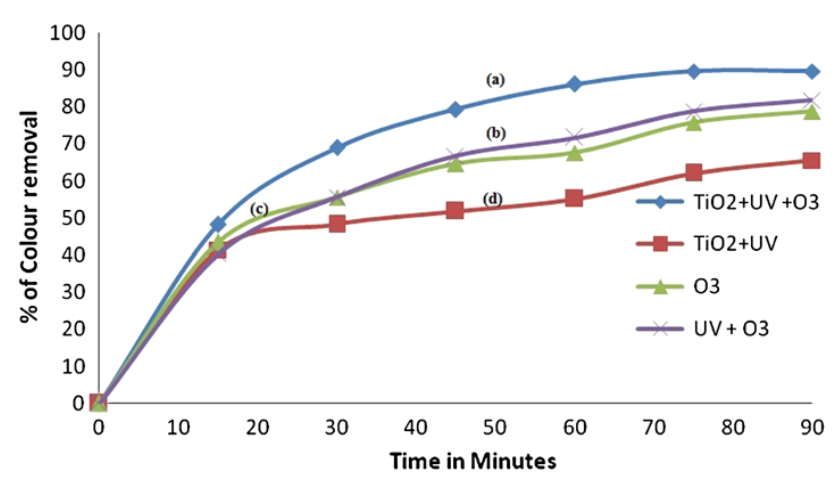

Fig. 7 Comparative studies on dye removal efficiency with (Rotation speed $=1,000 \mathrm{rpm}$, initial concentration of the dye $=1,000 \mathrm{ppm}) \quad a \quad \mathrm{TiO}_{2}+\mathrm{UV}+\mathrm{O}_{3} \quad b \quad \mathrm{UV}+\mathrm{O}_{3} \quad c \quad \mathrm{O}_{3}$ $d \mathrm{TiO}_{2}+\mathrm{UV}$

the presence of UV and semiconductor catalyst has higher potential to decolourize the textile dyes and is recommended for real-time textile effluent treatment system.
Open Access This article is distributed under the terms of the Creative Commons Attribution License which permits any use, distribution, and reproduction in any medium, provided the original author(s) and the source are credited.

\section{References}

Akyol A, Yatmaz HC, Bayramoglu M (2004) Photocatalytic decolorization of Remazol Red RR in aqueous $\mathrm{ZnO}$ suspensions. Appl Catal B Environ 54:19-24

Alaton IA, Gursoy BH, Schmidt J-E (2008) Advanced oxidation of acid and reactive dyes: effect of Fenton treatment on aerobic, anoxic and anaerobic processes. Dyes Pigments 78:117-130

Albu SP, Ghicov A, Macak JM, Hahn R, Schmuki P (2007) Selforganized free-standing $\mathrm{TiO} 2$ nanotube membrane for flowthrough photocatalytic applications. Nano Lett 7(5):1286-1289

Ananthashankar R, Ghaly A (2013a) Photocatalytic decolourization of textile effluent containing Reactive Red 120 dye with UV/ $\mathrm{TiO}_{2}$. Am J Eng Appl Sci 6:252-262

Ananthashankar R, Ghaly A (2013b) Effectiveness of photocatalytic decolourization of Reactive Red 120 dye in textile effluent using $\mathrm{UV} / \mathrm{H}_{2} \mathrm{O}_{2}$. Am J Environ Sci 9:322-333

Ankita V, Shamta N, Inderjeet Y, Shipra B (2013) Heterogeneous photocatalytic degradation of azure B: measurement of kinetic parameters and effluent treatment using solar energy. Res J Chem Sci 3:60-65

Baban A, Yediler A, Lienert D, Kemerdere N, Kettrup A (2003) Ozonation of high strength segregated effluents from a woollen textile dyeing and finishing plant. Dyes Pigments 58:93-98

Chin A, Bérubé PR (2005) Decomposition of disinfection by-product precursors with ozone-UV advanced oxidation process. Water Res 39:2136-2144

Ehrampoush MH, Moussavi GHR, Ghaneian MT, Rahimi S, Ahmadian M (2011) Decomposition of methylene blue dye from textile simulated sample using tubular reactor and $\mathrm{TiO}_{2} / \mathrm{UV}-\mathrm{C}$ photocatalytic process, Iran. J Environ Health Sci Eng 8:35-40

Fiola R, Luce R (1998) Wastewater for the blue jeans processing industry. Am Dyest Rep 87:54-55

Giwa A, Nkeonye PO, Bello KA, Kolawole EG (2012) Solar photocatalytic degradation of reactive yellow 81 and reactive violet 1 in aqueous solution containing semiconductor oxides. Int J Appl Sci Technol 2:90-105

Hussein FH, Abass TA (2010) Photocatalytic treatment of textile industrial wastewater. Int J Chem Sci 8:1353-1364

Joshi KM, Shrivastava VS (2011) Degradation of Alizarine Red-S (A Textiles Dye) by photocatalysis using $\mathrm{ZnO}$ and $\mathrm{TiO}_{2}$ as photocatalyst. Int J Environ Sci 2:8-21

Kansal SK, Singh M, Sud D (2007) Studies on photodegradation of two commercial dyes in aqueous phase using different photocatalysts. J Hazard Mater 141:581-590

Karuppuchamy S, Ito S (2008) Cathodic electrodeposition of nanoporous $\mathrm{ZnO}$ thin films from new electrochemical bath and their photoinduced hydrophilic properties. Vacuum 82:547-550

Kauppuchamy S, Jeong J-M (2006) Synthesis of nano-particles of $\mathrm{TiO}_{2}$ by simple aqueous route. J Oleo Sci 55:263-266

Kawahara T, Miyazaki H, Karuppuchamy S, Matsui H, Ito M, Yoshihara M (2007a) Electronic nature of vanadium nitridecarbon cluster composite materials obtained by the calcination of oxovanadylphthalocyanine. Vacuum 81:680-685

Kawahara T, Kuroda T, Matsui H, Mishima M, Karuppuchamy S, Seguchi Y, Yoshihara M (2007b) Electronic properties of calcined materials from a scandium- $O$-phenylene- $O$-yttrium- $O$ phenylene hybrid copolymer. J Mater Sci 42:3708-3713 
Khataee AR, Vatanpour V, Amani Ghadim AR (2009a) Decolorization of C.I. acid blue 9 solution by UV/nano-TiO ${ }_{2}$, Fenton, Fenton-like, electro-Fenton and electrocoagulation processes: a comparative study. J Hazard Mater 161:1225-1233

Khataee AR, Pons MN, Zahraa O (2009b) Photocatalytic degradation of three azo dyes using immobilized $\mathrm{TiO}_{2}$ nanoparticles on glass plates activated by UV light irradiation: influence of dye molecular structure. J Hazard Mater 168:451-457

Lomora M, Draghici C, Enesca Al (2011) Intermediary compounds in advanced oxidation processes for wastewater treatment. Eng Sci 4(53):52-58

Marathe SD, Shrivastava VS (2013) Synthesis of nano sized $\mathrm{TiO}_{2}$ and its application in photocatalytic decomposition of methylene blue. Adv Appl Sci Res 4:212-218

Matsui H, Yamamoto S, Izawa Y, Karuppuchamy S, Yoshihara M (2007a) Electron transfer behavior of calcined material obtained from a samarium- $O$-phenylene-S-nickel-S-phenylene- $O$ hybrid copolymer. Mater Chem Phys 103:127-131

Matsui H, Karuppuchamy S, Yamaguchi J, Yoshihara M (2007b) Electronic behavior of calcined materials obtained from $\mathrm{SnO}_{2}$ hydrosol/starch composite materials. J Photochem Photobiol A Chem 189:280-285

Matsui H, Kira K, Karuppuchamy S, Yoshihara M (2009) The electronic behaviors of visible light sensitive $\mathrm{Nb}_{2} \mathrm{O}_{5} / \mathrm{Cr}_{2} \mathrm{O}_{3}$ / carbon clusters composite materials. Curr Appl Phys 9:592-597

Meric S, Kaptan D, Olmez T (2004) Color and COD decomposition from wastewater containing Reactive Black 5 using Fenton's oxidation process. Chemosphere 54:435-441

Muruganandham M, Swaminathan M (2004) Solar photocatalytic degradation of a reactive azo dye in $\mathrm{TiO}_{2}$-suspension. Sol Energy Mater Sol Cells 81:439-457

Muruganandham M, Sobana N, Swaminathan M (2006) Solar assisted photocatalytic and photochemical degradation of Reactive Black 5. J Hazard Mater B 137:1371-1376
Neppolian B, Choi HC, Sakthivel S, Arabindoo B, Murugesan V (2002) Solar light induced and $\mathrm{TiO}_{2}$ assisted degradation of textile dye reactive blue 4. Chemosphere 46:1173-1181

Papic S, Koprivanac N, Bozic AL (2000) Decomposition of reactive dyes from wastewater using $\mathrm{Fe}(\mathrm{III})$ coagulant. J Soc Dyers Colour 116:352-359

Saggioro EM, Oliveira AS, Pavesi T, Maia CG, Ferreira LFV, Moreira JC (2011) Use of titanium dioxide photocatalysis on the remediation of model textile wastewaters containing azo dyes. Molecules 16:10370-10386

Schulze-Rettmer R (1998) Treatment of textile dyeing wastewater by adsorption/bio-oxidation process. Text Chem Color 30:19-23

Shah MP, Patel KA, Nair SS, Darji AM (2013) An innovative approach to biodegradation of textile dye (Remazol Black B) by bacillus spp. Int J Environ Bioremed Biodeg 1:43-48

Š́ma J, Hasal P (2013) Photocatalytic degradation of textile dyes in a $\mathrm{TiO}_{2} / \mathrm{UV}$ system. Chem Eng Trans 32:79-84

Sökmen M, Özkan A (2002) Decolourising textile wastewater with modified titania: the effects of inorganic anions on the photocatalysis. J Photochem Photobiol A Chem 147:77-81

Tang C, Chen V (2004) The photocatalytic degradation of reactive black 5 using $\mathrm{TiO}_{2} / \mathrm{UV}$ in an annular photoreactor. Water Res 38:2775-2781

Yi Sijia, Sun Leming, Lenaghan Scott C, Wang Yongzhong, Chong Xinyuan, Zhang Zhili, Zhang Mingjun (2013) One-step synthesis of dendritic gold nanoflowers with high surface-enhanced Raman Scattering (SERS) property. RSC Adv 3:10139-10144

Zhou H, Smith DW (2002) Advanced technologies in water and wastewater treatment. J Environ Eng Sci 1:247-264 